\title{
Pride, Faith, and Fear: Islam in Sub-Saharan Africa
}

Charlotte A. Quinn and Frederick Quinn USA: Oxford University Press, 2003. 175 pages.

If the real value of a book - any book - comes from its ability to present itself as a subject of various, but not contradictory, readings, this book undoubtedly fulfils that value. From the point of view of a Muslim and nonwestern reader, the book reflects the western fear of Islam as a power in crisis but adopts a line of argument against mainstream western writings on 
Islam. In other words, it argues against the prevalent claim that Islam, especially after the collapse of communism, represents the most dangerous threat to western values. Further, the book suggests that "opportunities for positive engagement with Africa's Muslim communities and states abound on the political, social, religious, economic, and cultural level" (p. 150).

Motivated by the need "to find a reasonable avenue of exploration and accommodation with countries and cultures that differ from our own (the Western culture)," the book unveils the mutual misunderstanding between the West and the Muslim world. Thus, it argues that the "Muslim world is treated (by the West) as having a single dimension, as if Muslims in general had bonded with Osama bin Laden" (p. 4). It also argues that the West sees Muslims as "stubbornly holding the idea that Christians have not abandoned the Crusaders' mentality, zealously trying to destroy all traces of Muslim civilizations in their entirety" (p. 4). Being aware of the harmful impacts of these misleading images not only on the media, but also - and this is the most dangerous - on the "contemporary (academic) analysis," the book invites the People of the Book ( $a h l$ al-kitab) to work together toward peace and reconciliation, emphasizing that "it will be a difficult but not impossible road." Without this effort to make peace, the book suggests, there will be chaos and violence.

Addressing the crisis of Islam or of Muslims, in fact, the book does not neglect the glorious past of Islam in Africa. For the authors of the book, it was Islam, or rather Muslim trade, "that linked Africa (earlier in the eleventh century) to the wider world and put it on the maps of time" (p. 18).

One of the main goals of the book is to draw our attention to the fact that the attempts made by the reformists and jihadists of the eighteenth and nineteenth centuries to solve their societies' problems were failures. Their recipes could neither respond creatively to modern challenges nor absorb the most human and progressive implications of recent world developments.

In practical terms, the book focuses on the problems that Muslims are facing in five African countries, problems that might develop into a suitable environment for violence and disorder. The main characteristics of these problems are seen to be economic in nature, for all African countries (not only the five countries being analyzed) suffer from an economic decline that the authors assert is linked to governmental corruption and inefficiency. This justifies the happy solution adopted by authors: These problems can be solved by replacing corrupt regimes with uncorrupted ones. Within this context, the West's only responsibilities are to provide economic and technical 
assistance to the African people and improve economic conditions by creating jobs so that unemployed youths will not become the fuel for terrorism.

Speaking of terrorism, the West, after long centuries of plundering and exploiting Africa's resources is now, supposedly, going to see Africa through sympathetic and helpful eyes. But that is only because of its own fear of terrorism. In my judgement, insofar as relations between the current western interest in Africa and the fear of terrorism can be established, it can be said that Islam also brings Africa to our maps once again. But while Islam in the past was a means to civilize and urbanize Africa, it is now an instrument to create violence and protest.

The book asserts that violent protests in Africa must be seen as the product of its local circumstances and not as an extension of Middle Eastern violence. But in doing this, the book tries to isolate African Muslims ("black" Islam) from its Arabic source. Paradoxically, it seems that Africa is beginning to resemble the Middle East as an arena of confrontation between Islam and the West. So, the book calls for a strategy to "save Africa" through economic and technical aid programs devised and funded by the West. Such an undertaking, the authors claim, will help Africa fight the penetration of so-called "Arab" terrorism.

The five countries analyzed, except for South Africa, continue to suffer from political and economic decline. Muslims, especially in countries where they are the majority, believe that the only way to remove this problem is to implement the Shari ah. This has led to the emergence of transforming the Shari'ah into a political program. By applying Islamic law, Sudan, for example, has established benchmarks for peace and stability, which, in turn, has encouraged trade and the enrichment of its domain (p. 19). However, in many countries, among them Nigeria and Sudan, the Shari ah has been politicized, while elsewhere (e.g., Kenya and South Africa), it was only implemented as a personal family law (p. 11). In both cases, however, the Shari ah can be seen as a political ideology or a sign of identity that "assumes a major importance for Muslims, representing the glue that holds society (or community) together."

Finally, speaking historically, the book contends that Islam was the religion that linked Africa to the wider world and put it on the maps of the time (p. 18). 